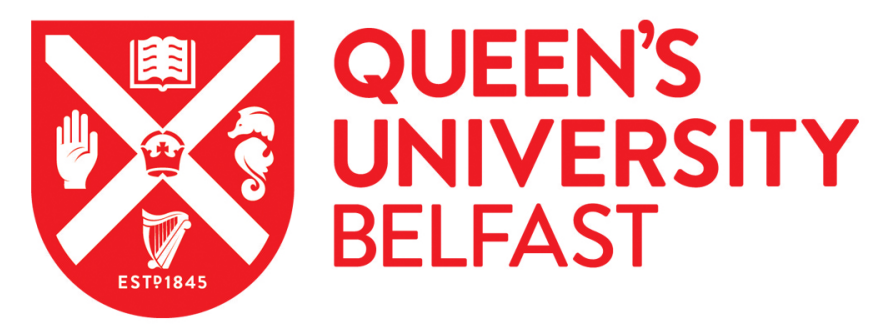

\title{
Irish Credit Unions: Differential Regulation based on Business Model Complexity
}

McKillop, D. G., \& Quinn, B. (2017). Irish Credit Unions: Differential Regulation based on Business Model Complexity. The British Accounting Review, 49(2), 230. https://doi.org/10.1016/j.bar.2016.07.001

\author{
Published in: \\ The British Accounting Review
}

Document Version:

Peer reviewed version

Queen's University Belfast - Research Portal:

Link to publication record in Queen's University Belfast Research Portal

Publisher rights

(c) 2016 Elsevier B.V. This manuscript version is made available under the CC-BY-NC-ND 4.0 license

$\mathrm{http}: / /$ creativecommons.org/licenses/by-nc-nd/4.0/,which permits distribution and reproduction for non-commercial purposes, provided the author and source are cited.

\section{General rights}

Copyright for the publications made accessible via the Queen's University Belfast Research Portal is retained by the author(s) and / or other copyright owners and it is a condition of accessing these publications that users recognise and abide by the legal requirements associated with these rights.

Take down policy

The Research Portal is Queen's institutional repository that provides access to Queen's research output. Every effort has been made to ensure that content in the Research Portal does not infringe any person's rights, or applicable UK laws. If you discover content in the Research Portal that you believe breaches copyright or violates any law, please contact openaccess@qub.ac.uk. 


\section{Accepted Manuscript}

Irish credit unions: Differential regulation based on business model complexity

Donal G. McKillop, Barry Quinn

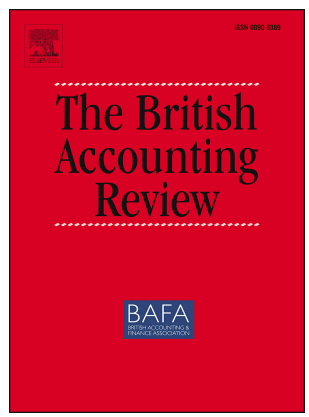

PII:

$$
\text { S0890-8389(16)30017-8 }
$$

DOI:

10.1016/j.bar.2016.07.001

Reference: $\quad$ YBARE 721

To appear in: The British Accounting Review

Received Date: 20 November 2015

Revised Date: 14 July 2016

Accepted Date: 25 July 2016

Please cite this article as: McKillop, D.G., Quinn, B., Irish credit unions: Differential regulation based on business model complexity, The British Accounting Review (2016), doi: 10.1016/j.bar.2016.07.001.

This is a PDF file of an unedited manuscript that has been accepted for publication. As a service to our customers we are providing this early version of the manuscript. The manuscript will undergo copyediting, typesetting, and review of the resulting proof before it is published in its final form. Please note that during the production process errors may be discovered which could affect the content, and all legal disclaimers that apply to the journal pertain. 
Irish Credit Unions: Differential Regulation based on Business Model Complexity

Donal G McKillop ${ }^{\mathrm{a}}$, Barry Quinn ${ }^{\mathrm{b}}$

\section{Abstract}

This study examines the business model complexity of Irish credit unions using a latent class approach to measure structural performance over the period 2002 to 2013. The latent class approach allows the endogenous identification of a multi-class framework for business models based on credit union specific characteristics. The analysis finds a three class system to be appropriate with the multi-class model dependent on three financial viability characteristics. This finding is consistent with the deliberations of the Irish Commission on Credit Unions (2012) which identified complexity and diversity in the business models of Irish credit unions and recommended that such complexity and diversity could not be accommodated within a one size fits all regulatory framework. The analysis also highlights that two of the classes are subject to diseconomies of scale. This may suggest credit unions would benefit from a reduction in scale or perhaps that there is an imbalance in the present change process. Finally, relative performance differences are identified for each class in terms of technical efficiency. This suggests that there is an opportunity for credit unions to improve their performance by using within-class best practice or alternatively by switching to another class.

aQueen's Management School, Queen's University Belfast, Northern Ireland, BT9 5EE, E-mail dg.mckillop@qub.ac.uk, Tel: +44 (0)28 90974852; fax: +44 (0)28 90974201

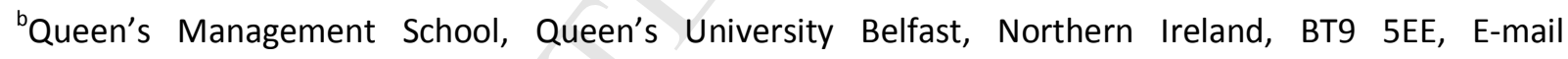
b.quinn@qub.ac.uk, Tel: +44 (0)28 90974824; fax: +44 (0)28 90974201 


\section{Introduction}

A Commission for Irish credit unions was established in 2011 to assess the legislative framework and the business practices of Irish credit unions. The Commission Report (2012) has led to the introduction of new legislation for credit unions and the establishment of a Credit Union Restructuring Board to facilitate amalgamations within the sector. ${ }^{1}$ The Commission contended that complexity in the business models of Irish credit unions could not be accommodated within a one size fits all framework. The appropriate number of classes necessary to accommodate this business model complexity has been subject to much debate. The Commission advocated three classes. The Credit Union Regulator, Central Bank of Ireland, has proposed a two-class framework (Central Bank of Ireland, 2013). The Irish League of Credit Unions, the primary trade body for credit unions in Ireland, while advocating a differentiated approach to the regulation of credit unions of different scales and complexity was undecided as to the number of classes and at what stage these classes should be introduced (Irish League of Credit Unions, 2014).

In this study we seek to shed light on this debate. A modelling technique is employed which uses credit union characteristics to provide insight into both the likelihood of a multi-class model and the optimal number of classes. We model the structural business model of a credit union as a production technology using an enhanced hyperbolic distance function. This distance function is estimated parametrically using a stochastic frontier approach (Aigner, Lovell \& Schmidt, 1977; Battese \& Corra, 1977; Nahn \& Vu, 2013). A latent class structure is introduced to the stochastic frontier to capture unobserved differences in a credit union's production technology that might otherwise be labelled as inefficiency. The latent class stochastic hyperbolic distance frontier model enables a multi-class model to be estimated, rather than determined ex-ante. The multi-class model and the membership of credit unions in each class are modelled in terms of the financial viability features of individual credit unions. The analysis is undertaken for credit unions over the period 2002 to 2013.

Credit unions are cooperative financial institutions. They are owned by their members and can only provide services to their members. Credit unions are not-for-profit financial institutions. Any surplus they generate is either reinvested in the credit union or returned to members in the form of dividends

\footnotetext{
${ }^{1}$ The Credit Union and Co-operation with Overseas Regulators Act 2012 (2012 Act) was enacted in December 2012 and the Credit Union Restructuring Board was established in January 2013. The Irish Government has allocated $€ 250$ million to aid the amalgamation process. By July 2015, the Credit Union Restructuring Board had successfully completed 29 transfer of engagements (mergers) involving 67 credit unions (ReBo Communique, July 2015).
} 
or interest rebates. The first credit union was formed in Ireland towards the end of the 1950s. Throughout the following three decades there were a large number of new formations. During the 1990s the level of new establishments reduced significantly and credit union numbers peaked at 435 in 1999. More recently there has been a small number of transfer of engagements and two credit union liquidations. ${ }^{2}$ In June 2015 there were 376 Irish credit unions with 2.6 million members and $€ 14.2$ billion of assets (Central Bank of Ireland, 2015). Irish credit unions primarily lend in the short-term (less than five year) personal loan market. Extreme pressures placed on Irish households from the collapse of property prices, and subsequent financial austerity measures implemented by the Government, has led to a severe and sustained downturn in their primary market (Glass, McKillop \& Quinn, 2014). This in turn has revealed significant weakness in the Irish credit union business model with, for example, average loans to asset ratios falling from 52 percent in 2008 to 28 percent in 2015.

Our analysis provides for a rich set of findings. First, a three class system is found to be optimal for Irish credit unions. Second, this optimal multi-class model is found to be dependent on three financial viability characteristics. They are the loan book as a percentage of total assets, the ability to generate an operational surplus and the capital adequacy position. Third, there are found to be distinct differences across each of the classes in terms of structural performance but there are broad similarities vis à vis scale economies. Two of the three classes are subject to diseconomies of scale at the mean. This may suggest that credit unions would benefit from a reduction in scale or perhaps that credit unions are not being permitted by the regulatory environment to provide the range of products and services consistent with their investment in staff and infrastructure. Fourth, relative technical efficiency performance differences are identified for each class. This suggests that credit unions can improve their performance by using within-class best practice or alternatively by switching to another class. Finally, the analysis highlights that an investigation based on a common frontier, which fails to recognise heterogeneity across credit unions, can be expected to overestimate the level of technical efficiency within the sector.

In summary, this study is the first to endogenously identify the existence of a multi-class business model for a credit union movement and to highlight that three classes are optimal. Although the analysis is based on Irish credit unions the results have applicability to credit union movements elsewhere. Credit unions worldwide are homogeneous in form with many credit union movements facing similar

\footnotetext{
2 Newbridge Credit Union and Berehaven Credit Union were liquidated November 2013 and April 2014 respectively.
} 
challenges to those in Ireland. ${ }^{3}$ A number of credit union movements are also currently exploring the appropriateness of tiered regulation for different classes of credit union based on either asset size or business model complexity, for example the UK and Canada. ${ }^{4}$ The rest of the paper is organised as follows. Section 2 reviews the literature on what sets credit unions apart as a financial form and the literature on structural performance assessment of financial institutions. In Section 3 we set out the methodological approached adopted. Section 4 profiles the variables used and provides a preliminary overview of the data. Section 5 details our primary findings. Section 6 presents a concluding commentary.

\section{Literature Review}

\subsection{Irish Credit Unions}

Credit unions are cooperative organisations. The International Cooperative Alliance (ICA) defines a cooperative as: "an autonomous association of persons united voluntarily to meet their common economic, social and cultural needs and aspirations through a jointly-owned and democraticallycontrolled enterprise" (ICA, 2015, p.2). This definition emphasises the voluntary and open nature of membership as well as the importance of democratic principles. Although membership to the credit union is open to all irrespective of age, gender or race, members must nevertheless satisfy a common bond. The common bond tends to be determined by locality, community-based common bond, or employer, work-based common bond (McKillop, Goth \& Hyndman, 2006). A key benefit of the common bond is that it reduces asymmetric information imbalances and in so doing facilities credit unions in providing financial services to those who otherwise might be excluded from the banking system (McKillop \& Wilson, 2011; Birchall, 2013). As the credit union can only provide services to its members (customers), this lowers the credit union's cost of information gathering over multiple products. Such benefits to credit unions can result in the additional supply of credit to members. This is achieved through lower credit prices and/or through an enhanced quantity of credit (Rubin, Overstreet, Beling \& Rajaratnam, 2012).

\footnotetext{
${ }^{3}$ Worldwide, there are 57,000 credit unions serving 217 million people in 105 countries (WOCCU, 2015).

${ }^{4}$ In the UK credit unions are categorised as either Version 1 or Version 2. Version 2 credit unions are provided with much greater product flexibility but face stiffer regulatory requirements. Only $4 \%$ of credit unions are Version 2 and given the limited take up of Version 2 status there is debate at present about the appropriateness of the twotiered framework (Tischer, Packman \& Montgomerie, 2015). In Ontario Canada differentiated requirements are placed on credit unions depending on their asset size. A recent review carried out at the behest of the Minister of Finance argues that a more appropriate approach would be to tailor regulatory requirements to business complexity (Albanese, 2015).
} 
Irish credit unions date from the late 1950s with the first community-based credit union formed in Dublin in 1958. The credit union movement grew rapidly until the end of the 1980s. During the 1990s the growth in new formations declined to approximately four per annum with credit union numbers peaking at 435 in 1999. Prior to the financial crisis (end year 2006) credit union numbers had reduced to just over 400 although membership and assets under their control continued to increase to 2.6 million and $€ 12.8$ billion respectively. In 2006 the average cost to income ratio was 50 percent, loans in arrears over 9 weeks were averaging at 6 percent, the average dividend rate was 2.1 percent, the loan book as a percentage of total assets was 47 percent and the average return on assets was 3.3 percent. More recent statistics depict a very different situation. In June 2015 there were 376 credit unions with 2.6 million members and $€ 14.2$ billion of assets. However, the average cost to income ratio was 65 percent, loans in arrears over 9 weeks were averaging 16 percent, the average dividend rate was 0.7 percent, the loan book as a percentage of total assets was 28 percent and the average return on assets was 1.6 percent (Central Bank of Ireland, 2015).

\subsection{Performance Assessment of Credit Unions}

There is a large and growing volume of empirical literature on structural performance in banking but a more limited literature for credit unions (Worthington, 2010). Those studies which have been undertaken on credit unions tend to concentrate on the more advanced movements where the data is most readily available, for example the US, Canada and Australia. ${ }^{5}$ In the case of Ireland, the majority of research is also concentrated on banks. Glass and McKillop (1991) used a cost function to investigate economies of scope, economies of scale and technical change for the two main Irish banks (Bank of Ireland and Allied Irish Bank). They found that these banks were subject to diseconomies of scale, that there was no production cost advantage in jointly producing loan and investment products, and that technical change had made a significant contribution to the growth of bank output. Lucey (1993) estimated a profit function. He found that Irish banks suffer from significant levels of inefficiencies amounting to approximately 13 percent of average profits. Fitzpatrick and McQuinn (2005) use both parametric and non-parametric techniques to consider the efficiency of Irish and UK banks. They found Irish banks to be four percent less efficient than their UK counterparts. Beck (2014), in a review of the medium and longer term prospects for the Irish banking system, concluded that banks should place much greater emphasis on enterprise relative to household credit provision. He also concluded that the

\footnotetext{
5 See McKillop et al. (2011) for an overview of studies on credit union efficiency and Worthington (2010) for a review of efficiency studies for financial mutuals.
} 
banks should place greater importance on providing financial services for the local economy rather than focusing on activities generated by way of the Irish Financial Services Centre (IFSC). As banks alter their focus he stressed the need for a fine tuning of both their lending policies and their risk management systems.

Only three studies have investigated the structural performance of credit unions in Ireland. McKillop and Quinn (2009) consider relative cost efficiency using stochastic frontiers. The study finds most credit unions not to be functioning at optimal levels and that there was a wide variation in performance. The reasons behind performance differences were explained by variations in technological sophistication, resources supplied by sponsors and bad debt write-offs.

Glass, McKillop and Rasaratnam (2010) use a two stage empirical approach. The first stage computes efficiency using a Data Envelopment Analysis (DEA) estimator. The second stage employs regression analysis to identify those factors which influence efficiency. The analysis uses 2006 data for the population of credit unions. Only seven percent of credit unions were identified as best practice credit unions with the rest subject to various degrees of inefficiency. Most operational variables were found not to influence credit union efficiency; the only exceptions were the dividend paid to members and the bad debt write-off ratio. An innovative feature of the analysis was that it also considered the impact on efficiency of Central Bank regulatory requirements such as directives on bad debts. The analysis revealed that almost 70 percent of credit unions did not face an additional opportunity cost from bad debt compliance requirements. ${ }^{6}$

Glass et al. (2014) consider credit union performance between 2002 and 2010. The modelling procedure explicitly considers the production of undesirable outputs as part of the input output process. Over the period credit unions were found to be subject to economies of scale. Although the effect was small, this finding was taken as supporting the restructuring process now underway whereby sector wide amalgamations are being promoted by a government sponsored restructuring board. The analysis also highlighted that efficiency could be significantly improved though expanding good outputs, such as loans and investments, and contracting less desirable outputs, such as loan and investment impairments. It was also found that loans and investment were good substitutes. This latter finding was used to suggest

\footnotetext{
6 For credit unions in Northern Ireland, Forker and Ward (2012) conclude that there is a positive association between self-regulation and financial ratios measuring prudence and loan book quality.
} 
that credit unions might benefit from legislative amendment to enable provision of a more diverse mix of financial products.

\subsection{Business model heterogeneity}

There is a small body of literature, which has considered heterogeneity in business model practices (in terms of production technologies). In financial services the work has concentrated solely on banks. The seminal paper is by Orea and Kumbhakar (2004). They introduce latent class structure to a parametric frontier to capture unobserved differences in a bank's production technology that might otherwise be labelled as inefficiency. The analysis uses an unbalanced panel of banks in Spain for the period 1992 to 2000. Four bank operational variables as well as the employee to bank branch ratio are used to determine the latent class probabilities with information criterion employed to identify the optimal number of classes. In the case of Spanish banks, heterogeneity is fully accounted for by a model based upon four classes. Mean cost efficiency for the sector was estimated to be 83 percent. There was however marked differences across the various classes with cost efficiency ranging from a low of 65 percent for class one to a high of 88 percent for the second class. An alternative methodology that also captures business model heterogeneity is the meta-frontier approach (Battese, Rao \& O'Donnell, 2004). This allows for the estimation of technology gap ratios between individual frontiers and the overall meta-frontier, which is derived as an envelopment of individual frontiers. Bos and Schmeidel (2007) estimate comparable efficiency scores for 5,000 large European banks. The analysis covers fifteen countries for the years 1993 to 2004. Two key findings emerge. First, the application of the metafrontier approach yields results broadly consistent with country specific findings. Second, the authors identified relatively small technology gap ratios which suggested that a single frontier may soon be applicable European wide. Casu, Ferrari and Tianshu (2013) use parametric (stochastic frontier) and nonparametric (data envelopment analysis) approaches to examine productivity growth in Indian banking during separate periods of deregulation and reregulation. The key finding is that parametric and nonparametric approaches yield a broad similarity in findings and that deregulation is centrally important in generating productivity growth. ${ }^{7}$

\footnotetext{
7 The use of the meta-frontier approach is appropriate in these three studies as these studies focus on pre-defined groupings - countries in Bos et al. (2007), regions in Battese et al. (2004), and ownership types in Casu et al. (2013). In our investigation the objective is to identify the optimal number of classes with no a priori assumption made about distinct groupings. The latent class stochastic hyperbolic distance frontier model, used in our investigation, enables a multi-class model to be estimated, rather than determined ex-ante.
} 


\section{Methodology}

The structural business model of a credit union is modelled as a production technology using an enhanced hyperbolic distance function (Glass et al., 2014). This distance function is estimated parametrically using a stochastic frontier approach (Aigner et al., 1977; Battese et al., 1977). A distance function provides a conventional parametric platform that allows for standard statistical inference based on a multiple input multiple output production technology. In the context of a credit union one appealing feature of the distance function is that it allows for the description of the structural business model without the need for behavioural assumptions. This can be problematic given the not-for-profit nature of these institutions (Bauer, 2008).

Traditionally, structural performance (productive efficiency) is measured using an 'average' credit union approach which uses a common frontier (Worthington, 1998). This approach assumes that all credit unions are subject to the same best practice catch-up (efficiency improvements) and scale economies potential. This would imply that all credit unions experience the same growth patterns regardless of their business model characteristics. A common frontier approach may not be representative if such growth patterns are not 'common' across all credit unions and the corresponding 'average' parameter estimates are less informative about what factors influence an individual credit union's performance potential.

Credit unions in Ireland due to their size differences and divergent lines of business can be argued to exhibit latent clustering, which if ignored can be misinterpreted as improvements or reductions in productive performance (Orea et al., 2004). This misspecification could distort the measurement of scale economies which are calculated utilising the parameter estimates of the distance function. Standard stochastic frontier analysis usually requires homogenous production function groups of credit unions to be identified beforehand. This is normally achieved using static industry classifications, which can be misleading. ${ }^{8}$ If the model ignores the above mentioned latent heterogeneity, estimates are likely to be biased (Greene, 2005).

Essentially a latent class frontier model focuses on technological (transformation function or service provision function) and inefficiency heterogeneity. To achieve a latent class framework a probabilistic model (a logit model which conditions class membership on financial viability characteristics) is

\footnotetext{
${ }^{8}$ One common solution to this firm level heterogeneity is to stratify the data into clusters according to some conditioning factor(s), then independently estimate cluster specific efficiency frontiers. Unfortunately, this is likely to result in biased frontiers since it does not consider the information in other clusters (Orea et al., 2004).
} 
augmented to a stochastic frontier model. These viability characteristics are capital adequacy, loan book as a proportion of the asset base and the Return on Assets (ROA). These characteristics capture the essence of a credit union's business model, the ability to on-lend while generating a surplus subject to having in place adequate capital buffers.

This innovative modelling structure allows credit unions to grow and improve their performance by catching up with best practice in a class or migration to a better class (switching). Unlike a standard one class model, credit unions are measured relative to distinct groups that are determined by key viability characteristic. The parameter estimates of the distance function are allowed to differ across groups and are estimated at the same time as the probability of group membership. As structural performance (efficiency) of credit unions in different technologies (classes) is measured simultaneously, but relative to different technologies (classes), we avoid the common approach of applying a one size fits all production function. This will provide a more accurate measure of scale and relative performance as well as the appropriate number of groups that best describe the sector.

The credit union's business model is modelled as a production process using an enhanced hyperbolic distance function. This allows for the transformation of a set of inputs into both good and bad outputs following an intermediation approach. A credit union's structural performance (production technology efficiency) is measured by the maximum equiproportionate expansion of good outputs and reduction of inputs and bad outputs. If the resultant credit union performance (technical efficiency) estimate is equal to 1 the credit union is deemed efficient. Scores less than 1 mean the credit union can improve performance by expanding the production of good outputs while contracting the production of bad outputs and input use. Credit unions that score less than 1 are deemed productively inefficient (for technical details see Glass et al., 2014).

\subsection{Estimation}

We employ a latent class stochastic frontier analysis (Aigner et al., 1977; Battese et al., 1977; Orea et al., 2004; Greene, 2005). A latent class structure is imposed to create the following distance function model:

$$
-\ln \left(y_{M i t}\right)=T L\left(x_{k i t}^{*}, b_{r i t}^{*}, y_{m i t}^{*} ; \boldsymbol{\alpha}_{z}, \boldsymbol{\beta}_{z}, \boldsymbol{\gamma}_{z}, \boldsymbol{\eta}_{z}, \boldsymbol{\rho}_{z}, \boldsymbol{\theta}_{z}\right)+v_{i t \mid z}-\ln \left(D_{E i t \mid z}\right)
$$

Where $x_{k i t}^{*}, b_{\text {rit }}^{*}$ and $y_{m i t}^{*}$ are transformed variables defined using the inputs, $x_{k i t}$, good outputs, $y_{m i t}$, and bad outputs, $b_{\text {rit }}$, of the $i^{\text {th }}$ credit union in year $t . \ln \left(D_{E i t \mid z}\right)$ is the resultant enhanced hyperbolic 
distance from the $z^{\text {th }}$ latent class production frontier, and represents technical inefficiency. For a detailed exposition of the model specification see the Appendix. ${ }^{9}$ To summarise the estimation, the Irish credit union industry's structural business model complexity is modelled using a set of equations: $Z$ enhanced hyperbolic distance functions and a multinomial logit model which uses a set of conditioning variables to sort credit unions into each of the $Z$ classes. Orea et al., $(2004$, p.6) note that the usefulness of the latent class approach is in the way it "uses the goodness of fit of each estimated frontier as additional information to identify groups of firms into each class".

\subsection{Scale Economies}

Scale economies at the mean can be calculated from distance function estimates by using the input and output elasticities from equation (1). Class level Returns to Scale (RTS) are calculated as RTS = $\left[\left(-2 \sum_{k} \alpha_{k \mid z}\right)-\gamma_{1 \mid z}\right]$ where $(<,=,>) 1$ implies (decreasing, constant, increasing) returns to scale. Global Returns to Scale (GRTS) are calculated as a probability weighted sum of the above and is given as

$$
G R T S=\sum_{z} \omega_{z} R T S_{z}=\sum_{z} \omega_{z}\left[\left(-2 \sum_{k} \alpha_{k \mid z}\right)-\gamma_{1 \mid z}\right]
$$

where $(<,=,>) 1$ implies (decreasing, constant, increasing) returns to scale. $\omega_{z}$ is the average probability of class membership which is estimated from the model. These measures provide an overview of scale economies at both sector level and latent class levels.

\section{Data}

The data set covers the period 2002 to 2013. The intermediation approach is used in the specifications of the inputs and outputs (Worthington, 2010). A three input (labour expenditure, capital expenditure and interest expenditure), three 'good' outputs (loans to members, other earning assets and shares and deposits) and a one 'bad' output (bad debt provisions) is specified. In the case of loans to members and other earning assets we use risk-adjusted outputs where these outputs are adjusted for non-performing loans and investment losses respectively (Hunter \& Timme, 1986; Park \& Weber, 2006). ${ }^{10}$ In Table 1 we provide data definitions for these inputs and outputs. The conditioning variables used in the analysis are aimed at capturing financial viability characteristics. They are ROA, capital adequacy and the loan to

\footnotetext{
${ }^{9}$ The latent class stochastic frontier approach used in this paper is a refinement of the work in Glass et al (2014) which assumed Irish credit unions to be homogeneous.

10 Mester (1996) argues that financial institution efficiency analysis provides misleading results when output quality and financial institution risk-taking is not explicitly modelled.
} 
asset ratio. These characteristics capture the essence of a credit union's business model, the ability to on-lend while generating a surplus subject to having in place adequate capital buffers. The respective conditioning variables are described in Table 1.

\section{INSERT TABLE 1}

In Table 2 some descriptive statistics are presented for the variables used in this study. For ease of exposition we have presented the information at set intervals - 2002, 2005, 2008, 2011 and 2013. A number of points emerge from this overview. From Table 2 (Panel A), it can be seen that lending has declined significantly since 2008. In 2008 credit unions on average had extended $€ 16$ million in loans to members by 2013 this had fallen to $€ 10.8$ million. This is not unexpected given the sustained economic pressures faced in Ireland in the post-crisis period. This lending decline has also been compounded by lending restrictions imposed on credit unions by the Central Bank as the financial crisis in Ireland deepened (Power, O'Connor, McCarthy \& Ward, 2014). ${ }^{11}$ The decline in the loan book has been matched by a corresponding increase in investments and linked assets (from an average of €14.8 million per credit union in 2008 to $€ 24.6$ million in 2013). This increase in investments is a problem because a large share of the investment portfolio is in the form of low earning assets such as bank deposits and shortterm government bonds (Irish and EU). The yield on both groups of assets has been extremely low in recent years (Department of Finance, 2015). A further point of note from Table 2 (Panel A), is that bad debt provisions have declined since peaking in 2008 and at the end of the estimation period were actually lower than at the start (the average credit union's bad debt provision was $€ 237,000$ in 2002, rising to $€ 614,000$ in 2008 before falling to $€ 181,000$ in 2013). The initial increase in the provisions figure was due to deterioration in the Irish economy and stricter provision requirements by the Central Bank.

Table 2 (Panel B) present a profile of inputs. Over the period there has been a sharp rise in labour and related costs (the average credit union's labour expenditure was $€ 158,000$ in 2002 , rising to $€ 288,000$ in 2008 and rising further to $€ 333,000$ in 2013). The new regulatory environment stemming from the Commission Report (2012) and the 2012 Act have imposed additional risk management and compliance requirements on credit unions. To meet these requirements many credit unions have employed risk management and compliance specialists. Table 2 (Panel C) details the financial viability characteristics. A clear trend is the deterioration in the loan book. The average loan to asset ratio was 56.95 percent in

\footnotetext{
${ }^{11}$ At the height of the financial crisis almost $70 \%$ of all credit unions were subject to lending restrictions. Almost all credit unions with a lending restriction in place had a maximum individual loan size restriction.
} 
2002 but by 2013 it had fallen to 32.62 percent. A strongly performing credit union should have a loan to asset ratio between 70 and 80 percent (WOCCU, 2002). At no stage between 2002 and 2013 did Irish credit unions come close to meeting the WOCCU criterion for a well-functioning credit union. A positive feature emerging from the financial characteristics component of Table 2 is the strength of the capital base of Irish credit unions. Capital adequacy has steadily increased over the period from 10.08 percent in 2002 to 15.79 percent in 2013. The Central Bank of Ireland requires credit unions to have reserves to assets of at least 10 percent.

INSERT TABLE 2

INSERT TABLE 3

\section{Empirical Findings}

The first stage in this investigation is to determine whether inefficiency exists. This is achieved through comparison of a fully efficient specification (non-frontier specification) with a systematic inefficient specification (translog with time trend specification). The likelihood ratio test, detailed in Table 3, confirms rejection of the non-frontier specification. The second step is to determine whether the common distance function model or a latent class distance function model is the preferred model. The likelihood ratio test in Table 3 confirms rejection of the common frontier specification and consequently the appropriateness of adopting a latent class specification.

The next step in the analysis is to determine if distinct production technologies (structural business model classes) exist for Irish credit unions over the period under investigation. That is, we must determine the number of classes, $Z$ for equation (1). This is done in a number of steps. Firstly, the maximum number of classes is determined by a comparison of log-likelihood values, joint significance of parameters and reduction in class sizes upon the addition of another class (Greene, 2005). This first step suggests a maximum of four classes. Secondly, the optimal number of classes is then determined using information criteria (Orea et al., 2004). Two information criteria statistics are used Akaike (AIC) and Schwarz Bayesian (SBIC). The results, provided in Table 4, identify a three class model conditioned on the viability characteristics of loan book as a percentage of total assets, ROA and capital adequacy as optimal. The three class model has the largest log-likelihood and the lowest (most negative) information criteria statistic.

INSERT TABLE 4 
Table 5 provides coefficient estimates for the latent class frontier model based on the three classes identified as optimal. For comparison purposes we have also detailed the coefficient estimates for the common frontier model which ignores class division. Table 5 provides convincing evidence that a three class model is appropriate in capturing the structural business model complexity of Irish credit unions. In Table 5 (Panel A) the parameter estimates for all three classes are highly significant and first order coefficient estimates on outputs and inputs are appropriately signed, illustrating the correct monotonic relationship between these variables and the production frontier (increasing in outputs and decreasing in inputs and undesirable (bad) output). The time trend in the model $\theta$ is a quantification of technical growth (regression). For each class there is a small positive but significant coefficient estimate, ranging from a value of 0.005 for class 1 and 2 to 0.022 for class 3 . This highlights that the most pronounced technical progress (improvement in production technology over time) occurs for those credit unions categorised within class 3 . The coefficient estimate of 0.022 suggests that the structural business model (production technology) faced by class 3 credit unions is on average increasing by approximately 2.2 percent per annum.

\section{INSERT TABLE 5}

Table 5 (Panel C) sets out the class membership probability parameter estimates. All parameter estimates are statistically significant reinforcing the fact that distinct classes exist in the modelling of the business model production process for Irish credit unions. Using class 3 credit unions as the reference group it can be seen that compared to this class ROA and capital adequacy have a positive influence on class 1 and 2 memberships. However, while loan book to assets also has a positive influence on the membership of class 1 it has a negative influence on membership of class 2 compared to the reference group (class 3). ${ }^{12}$ The prior probabilities of class membership (at the data means) indicate that class 1 contains 41 percent of the credit unions in the sample, class 2 contains 43 percent of credit unions and class 3 contains 16 percent.

Average technical efficiency scores are calculated from the parameter estimates detailed in Table 5 and are presented in Table 6 column two for each of the three latent classes. Again for comparison purposes the average efficiency score based on the assumption of a common frontier is also detailed. The average estimate of technical efficiency from the common frontier is 0.964 . The average technical efficiency

\footnotetext{
12 As a robustness test the model was rerun using orthogonalised transformations of the three condition variable to control for their potential correlated nature. Results were broadly consistent with the main findings.
} 
values from the latent class frontiers are 0.961 (class 1), 0.868 (class 2) and 0.951 (class 3). A comparison of these values highlight that an analysis based on a common frontier, which fails to recognise heterogeneity across credit unions, will overestimate the level of technical efficiency within the sector. The latent class technical efficiency values also suggest that class 2 is less efficient than class 3 which in turn is less efficient that class 1 . To illustrate how these technical efficiency values can be interpreted consider the technical efficiency score for class 2 . This average efficiency value of 0.868 (see Table 6) suggests that, relative to its production frontier, the average class 2 credit union, has a potential capability of increasing good outputs (loans, other earning assets and members' funds) by 15.21 percent $(1 / 0.868=1.1521)$, while at the same time reducing its bad output (bad debt provisions) and its inputs (labour, capital and interest expenses) by 13.2 percent $(1-0.868=0.132)$.

Table 6 also presents information on the average financial viability characteristics of each latent class. Class 2 credit unions are the most inefficient. This class of credit unions have the lowest loan book to asset ratio (38.19 percent) over the sample period. This group also has the highest capital adequacy ratio (13.94 percent) so are quite well protected from unexpected shocks in comparison to the other groups. Somewhat unexpectedly they are also identified as having the highest return on assets. Partly this is due to our investigative period, the latter half of which covers an extremely turbulent period for Irish credit unions. During this time many credit unions faced significant problems on their loan book in terms of loan impairments which paradoxically may have benefited those with poor lending capabilities such as those in class 2.

\section{INSERT TABLE 6}

We further considered the profile of credit unions in each class based on location, common bond type, trade association affiliation and asset size. This overview is detailed in Table 7. Limited differences are evident between the classes. A much smaller number of credit unions are categorised as class 3 compared to the other two classes. Class 1 has a higher proportion of urban and occupational credit unions. Class 2 are the largest by average asset size with a large percentage affiliated to the Irish League of Credit Unions.

\section{INSERT TABLE 7}

Information on scale economies is presented in Table 8 for each of the three latent classes. A global measure, the probability weighted sum of scale return measures for the individual classes, is also detailed and is defined as in equation (2). For comparison purposes a scale economies measure, based 
on the assumption of a common frontier, is also presented. The global measure and two of the individual latent class measures are significantly different from one as illustrated by their 95 percent confidence interval. In each instance diseconomies of scale pertain. The latent scale measure for class 2 is also less than 1 but the confidence interval indicates that the null hypothesis of constant returns to scale cannot be rejected. In the case of the scale measure, based on the common frontier, we also cannot reject the null hypothesis of constant returns to scale. The difference between the global weighted and the common frontier measures again highlight the importance of adopting a latent class structure. Failure to recognise heterogeneity across credit unions will result in an overestimation of scale returns within the sector.

\section{INSERT TABLE 8}

The finding that diseconomies of scale are prevalent is of concern given the amalgamation process now underway. It is also at odds with the views expressed by the Credit Union Commission (2012) which identified mergers and amalgamations as an important strategy for those credit unions which wished to put in place a business model structured around enhanced scale. The finding also differs from that obtained by Glass et al. (2014) who, using a common frontier approach, found credit unions to be subject to economies of scale over the estimation period, 2002 to 2010 . To consider how scale economies have changed over time and to benchmark the findings in this paper with that of Glass et al. (2014), we present in Table 9 GRTS estimates based upon rolling windows. For the period 2002 to 2008 we find that the sector is subject to increasing returns to scale. Thereafter the GRTS value declines. However, for the next four windows, which include the sample period used by Glass et al. (2014), the null hypothesis of constant returns to scale cannot be rejected. Decreasing returns to scale hold for the period 2002 to 2013.

\section{INSERT TABLE 9}

The key issue for the sector, and why diseconomies of scale have been found to exist in this present study, is that credit unions are now subject to a very much strengthened regulatory framework, as complete and extensive as in the most sophisticated of credit union movements. However, this has not been matched by the Central Bank of Ireland allowing credit unions to adopt more permissive business models. For example, Section 35 of the Credit Union Act 1997 as amended by the Central Bank Reform 
Act 2010, limits the amount of lending credit unions can do over both 5 and 10 years. ${ }^{13}$ Furthermore in recent years some credit unions also have had loan restrictions placed on them by the Central Bank and this may also have adversely impacted their lending abilities, (Credit Union Advisory Committee, 2016). ${ }^{14}$ In essence credit unions have all the cost burden of the new regulatory framework but none of the benefits in terms of providing new products and services within expanded lending limits. It is of no surprise that in such an environment diseconomies of scale now present.

\section{Conclusion}

This study examines the structural business model complexity of credit unions in Ireland. A latent class procedure is employed to measure structural performance over the period 2002 to 2013 . The structural model rewards an increase in desirable (good) outputs and the reduction in both inputs and undesirable (bad) outputs. The latent class approach allows the endogenous identification of a multi-class business model based on credit union specific characteristics. A number of findings emerge which have a direct bearing on the change process now underway for Irish credit unions.

An initial finding is that a multi-class business model system for Irish credit unions is identified for the period 2002 to 2013. This optimal multi-class model is found to be dependent on three financial viability characteristics. They are a credit union's loan book to total assets, its ability to generate an operational surplus and its capital adequacy position. These findings have significant importance for Irish credit unions. The Commission Report (2012) identified complexity and diversity in the business models of Irish credit unions and recommended that such complexity and diversity could not be accommodated within a one size fits all regulatory framework. Our results, which have identified three classes of business model complexity, support the Commission's conclusion that a common regulatory framework for all credit unions is inappropriate.

A further conclusion emanating from this analysis is that there are differences between the classes with regard to scale economies and structural performance. In terms of scale economies, two classes are subject to diseconomies of scale, the null of constant returns to scale cannot be rejected for the third class. This may suggest that credit unions in two of the classes would benefit from a reduction in scale or

\footnotetext{
${ }^{13}$ To date 11 credit unions have sought approval to avail of increased longer term lending limits. Two of these credit unions currently operate within these increased lending limits. The other nine credit unions are still operating under the lower limits and are not utilising the increased limits.

${ }^{14}$ Credit Union Advisory Committee (2016) notes that that there are 85 credit unions with some form of lending restrictions. These restrictions are argued to have a very limited impact on the ability of a credit union to lend.
} 
perhaps that there is imbalance in the change process. We would argue that the latter is the case. Credit unions are now subject to a new and more costly regulatory environment, however, this has not been matched by opportunities to adopt more flexible business models within a more permissive lending framework. Under such a situation it is no surprise that class specific diseconomies of scale pertain. The analysis of GRTS further emphasised the deteriorating position of credit unions. A rolling window analysis highlighted that since 2008 the sector has moved from increasing returns to scale, to constant returns to scale and now to decreasing returns to scale.

Our study also highlighted that relative performance differences are identified for each class vis à vis technical efficiency. The latent class technical efficiency values highlight that class 2 is less efficient than class 3 which in turn is less efficient than class 1 . This suggests that there is an opportunity for credit unions to improve their performance by using within class best practice or alternatively by switching to another class. Finally, the analysis highlighted that an investigation based on a common frontier, which fails to recognise heterogeneity across credit unions, will overestimate the level of technical efficiency within the sector. 


\section{Appendix: Details of Model Estimation}

Extending the approach of Cuesta, Lovell, and Zofio (2009) we assume the latent class enhanced hyperbolic distance function is of the translog form with a constant rate of technical change, written as:

$$
\begin{gathered}
-\ln \left(y_{M i t}\right)=\alpha_{z}+\sum_{k=1}^{K} \alpha_{k \mid z} \ln x_{k i t}^{*}+\frac{1}{2} \sum_{k=1}^{K} \sum_{l=1}^{K} \alpha_{k l \mid z} \ln x_{k i t}^{*} \ln x_{l i t}^{*}+\sum_{m=1}^{M-1} \beta_{m \mid z} \ln y_{m i t}^{*} \\
+\frac{1}{2} \sum_{m=1}^{M-1} \sum_{n=1}^{M-1} \beta_{k l \mid z} \ln y_{k i t}^{*} \ln y_{l i t}^{*}+\sum_{r=1}^{R} \gamma_{r \mid z} \ln b_{r i t}^{*}+\frac{1}{2} \sum_{r=1}^{R} \sum_{s=1}^{R} \gamma_{r s \mid z} \ln b_{r i t}^{*} \ln b_{s i t}^{*} \\
+\sum_{m=1}^{K} \sum_{n=1}^{M-1} \rho_{k m \mid z} \ln x_{k i t}^{*} \ln y_{m i t}^{*}+\sum_{k=1}^{K} \sum_{s=1}^{R} \eta_{k r \mid z} \ln x_{k i t}^{*} \ln b_{r i t}^{*}+\sum_{m=1}^{M-1} \sum_{s=1}^{R} \phi_{m r \mid z} \ln y_{m i t}^{*} \ln b_{r i t}^{*}+\theta_{z} t \\
+v_{i t \mid z}-\ln \left(D_{E i t \mid z}\right)
\end{gathered}
$$

Where $x_{\text {kit }}^{*}, b_{\text {rit }}^{*}$ and $y_{\text {mit }}^{*}$ are transformed ${ }^{15}$ variables defined using the inputs, $x_{\text {kit }}$, good outputs, $y_{m i t}$, and bad outputs, $b_{\text {rit }}$, of the $i^{\text {th }}$ credit union in year $t . \ln \left(D_{E i t \mid z}\right)$ is the resultant enhanced hyperbolic distance from the $z^{\text {th }}$ latent class (tier) production frontier, and represents technical inefficiency. This technical inefficiency term is assumed to be non-negative and distributed independently as $N^{+}\left(0, \sigma_{u z}^{2}\right)$. The term $v_{i t} \mid z$, is identically and independently distributed as $N\left(0, \sigma_{v z}^{2}\right)$ and adds stochastic noise to the frontier estimations. The above specifications include a yearly index of time, $t$, which captures Hicks neutral constant technical change (or constant shift in the production frontier) over the period 2002-2013.

In the estimation of the model specification we must allocate each observation (it) to a class ( $z$ ). Prior probabilities of class membership are used to weight observations into the appropriate latent class by maximising the log-likelihood function using an EM algorithmic approach. For a detailed empirical exposition of this approach see (Bos, Economidou, Koetter \& Kolari., 2010).

${ }^{15}$ For details of transformation see Glass et al (2014). 


\section{Reference}

Aigner, D., Lovell, C. A. K, Schmidt, P. (1977). Formulation and estimation of stochastic frontier production function models. Journal of Econometrics, 6(1), 21-37.

Albanese, L. (2015). Credit Unions and Caisses Populaires Act, 1994, Legislative Review, Report to the Minister of Finance, November 2015, Ontario Canada.

Battese, G. E., Corra G. S. (1977). Estimation of a production frontier model: With application to the pastoral zone of Eastern Australia. Australian Journal of Agricultural Economics, 21(3), 169-179.

Battese, G. E., Rao, D. S. P., O'Donnell, C. J. (2004). A meta-frontier production function for estimation of technical efficiencies and technology gaps for firms operating under different technologies. Journal of Productivity Analysis, 21 (1), 91-103.

Bauer, K. (2008). Detecting abnormal credit union performance. Journal of Banking and Finance, 32(4), 573-86.

Beck, T. (2014). Ireland's banking system - looking forward. Working Paper, Trinity College Dublin, available on the internet at http://www.tcd.ie/iiis/assets/pdf/Jan102014Beck.pdf

Birchall, J. (2013). Resilience in a downturn. Geneva: International Labour Organization.

Bos, J. W. B., Schmiedel, H. (2007). Is there a single frontier in a single European banking market? Journal of Banking and Finance 31(7), 2081-2102.

Bos, J. W. B., Economidou, C., Koetter, M., Kolari, J. W. (2010). Do all countries grow alike? Journal of Development Economics, 91(1), 113-127.

Casu, B., Ferrari, A., Tianshu, Z. (2013). Regulatory reform and productivity change in Indian Banking. The Review of Economics and Statistics 95 (3), 1066-77.

Central Bank of Ireland. (2015). Credit Union News, Issue 3, August 2015, Central Bank of Ireland, Dublin.

Central Bank of Ireland. (2013). Consultation on the introduction of a tiered regulatory approach for credit unions, CP 76. Central Bank of Ireland, Dublin.

Credit Union Commission Report. (2012). Report of the Commission on Credit Unions. Irish Department of Finance, Dublin, available on the internet at http://drbq.co/CommissionReport2012 
Credit Union Asdvisory Committee (2016). Review of Implementation of the Recommendations in The Commission on Credit Union Reports. Irish Department of Finance, Dublin, available on the internet at http://drbq.co/ReviewCUcommissionReport

Cuesta, R. A., Lovell, C. A. K., Zofío, J. L. (2009). Environmental efficiency measurement with translog distance functions: A parametric approach. Ecological Economics 68, (8-9), 2232-2242.

Department of Finance. (2015). Credit Union Restructuring - ReBo. Section 43 Review, Dublin.

Fitzpatrick, T., McQuinn, K. (2005). Measuring bank profit efficiency. Technical Paper 3, Economic Analysis and Research Department, Central Bank and Financial Services Authority of Ireland.

Forker, J., Ward., A. M. ( 2012). Prudence and financial self-regulation in credit unions in Northern Ireland. British Accounting Review, 44(4), 221-234

Glass J.C., McKillop, D.G., Rasaratnam, S. (2010). Irish credit unions: Investigating performance determinants and the opportunity cost of regulatory compliance. Journal of Banking and Finance, 34 (1), 67-76

Glass, J. C., McKillop, D.G. (1991). Efficiency in Irish banking: theory and evidence. Applied Financial Economics, 1, 235-240.

Glass, J. C., McKillop, D.G., Quinn, B. (2014). Modelling the performance of Irish credit unions, 2002 to 2010. Financial Accountability and Management 30 (4), 430-53.

Greene, W., (2005). Reconsidering heterogeneity in panel data estimators of the stochastic frontier model. Journal of Econometrics, 126, 269-303.

Hunter, W. C., Timme, S.G., (1986). Technical change, organizational form, and the structure of bank production. Journal of Money, Credit, and Banking, 18(2), 152-166.

International Cooperative Alliance (ICA), (2015). What is a co-operative? Available at http://ica.coop/en/what-co-operative

Irish League of Credit Unions. (2014). Consultation on the introduction of a tiered regulatory approach for credit unions, Submission from the Irish League of Credit Unions, December 2014. Dublin

Lucey, B. (1993). Profits, efficiency and Irish banks. Report to Statistical and Social Inquiry Society of Ireland, 27 (1), 31-73 
McKillop, D. G., Wilson, J. O. S. (2011). Credit unions: A theoretical and empirical overview. Financial Markets, Institutions and Instruments, Leonard N, Stern School of Business, New York University, 20, 79-123.

McKillop, D. G., Goth, P., Hyndman, N. (2006). The Structure, Performance and Governance of Irish Credit Unions. Dublin: Institute of Chartered Accountants in Ireland, Ireland.

McKillop D. G., Quinn B. (2009). Cost Performance of Irish Credit Unions. Journal of Cooperative Studies, $42,(1), 22-36$.

Mester, L.J. (1996). A study of bank efficiency taking into account risk-preferences. Journal of Banking and Finance, 20(6), 1025-1045.

Nahn, D., Vu, H. T. (2013). Measuring scale efficiency from a parametric hyperbolic distance function. Journal of Productivity Analysis, 39(1), 83-88

Orea, L., Kumbhakar, S. C. (2004). Efficiency measurement using a latent class stochastic frontier model. Empirical Economics 29 (1), 169-83.

Park, K. H., Weber, W. L., (2006). A note on efficiency and productivity growth in the Korean banking industry, 1992-2002. Journal of Banking and Finance, 30(8), 2371-2386.

Power, C., O'Connor R., McCarthy, O., Ward, M. (2014). Merging into the mainstream? An empirically based discussion of the potential erosion of competitive advantage in a restructured Irish credit union movement. Journal of Co-operative Organization and Management, 2(2), 55-64

Rubin, G. M., Overstreet, G. A., Beling, P., Rajaratnam, K. (2012). A dynamic theory of the credit union. Annals of Operations Research 205 (1), 29-53.

Tischer, D., Packman C., Montgomerie, J. (2015). Gaining interest: A new deal for sustained credit union expansion in the UK, Political Economy Research Centre, Goldsmiths, University of London. Available at http://www.perc.org.uk/perc/wp-content/uploads/2015/06/Gaining-Interest$\underline{\text { Report.pdf }}$

World Council of Credit Unions, (WOCCU), (2002). PEARLS Monitoring System, World Council Information Center. Madison, Wisconsin, USA

World Council of Credit Unions, (WOCCU), (2015). Statistical Report, World Council Information Center. Madison, Wisconsin, USA 
Worthington, A. C. (1998). The determinants of non-bank financial institution efficiency: A stochastic cost frontier approach. Applied Financial Economics, 8(3), 279-87.

Worthington, A. C. (2010). Frontier efficiency measurement in deposit-taking financial mutuals: A review of techniques, applications, and future research. Annals of Public and Cooperative Economics, 81(1):39-75 


\section{Tables}

Table 1: Detailed description of model variables.

\begin{tabular}{|c|c|c|}
\hline Variable & Name & Description \\
\hline \multicolumn{3}{|c|}{ MODEL OUTPUTS } \\
\hline $\mathrm{Y}_{1}$ & Risk adjusted loans to members & $\begin{array}{l}\text { Total members loans adjusted for bad } \\
\text { debts written off. }\end{array}$ \\
\hline$Y_{2}$ & Risk adjusted earning assets & $\begin{array}{l}\text { Total of bank deposits, Irish and EU state } \\
\text { securities, life assurance products, } \\
\text { collective investment schemes and other } \\
\text { interest bearing investments. This figure } \\
\text { is adjusted for investment losses. }\end{array}$ \\
\hline$Y_{3}$ & Shares and Deposits & $\begin{array}{l}\text { Total member deposits and share } \\
\text { accounts. }\end{array}$ \\
\hline $\mathrm{b}$ & Bad debt proxy & Provisions for bad debt \\
\hline \multicolumn{3}{|c|}{ MODEL INPUTS } \\
\hline $\mathrm{X}_{1}$ & Labour expenses & Salaries and related expenses \\
\hline$x_{2}$ & Physical capital expenses & $\begin{array}{l}\text { Expenditures on: (i) premises and } \\
\text { associated, (ii) equipment and associated } \\
\text { (iii) depreciation and (iv) lease of } \\
\text { equipment. }\end{array}$ \\
\hline$X_{3}$ & Interest expenses & Dividends and deposit interest \\
\hline & & \\
\hline $\mathrm{T}$ & Time trend indicator & $\begin{array}{l}\text { An indicator variable that proxies for the } \\
\text { annual nature of the data }\end{array}$ \\
\hline \multicolumn{3}{|c|}{ FINANCIAL VIABILITY VARIABLES } \\
\hline L/TA & Gross Loan book/Total assets & $\begin{array}{l}\text { This measures the extent of lending to } \\
\text { members relative to the credit union's } \\
\text { asset base. }\end{array}$ \\
\hline ROA & Return on Assets & $\begin{array}{l}\text { This measures the surplus (deficit) } \\
\text { generated by the credit union relative to } \\
\text { its asset base. }\end{array}$ \\
\hline K/TA & Capital Adequacy & $\begin{array}{l}\text { This measures the reserves of the credit } \\
\text { union relative to its asset base. }\end{array}$ \\
\hline
\end{tabular}


Table 2: Descriptive statistics of model variables.

\begin{tabular}{|c|c|c|c|c|c|c|c|c|}
\hline \multicolumn{7}{|c|}{ Panel A: Model Outputs } \\
\hline & \multicolumn{2}{|c|}{$\begin{array}{c}\text { Loans to Members } \\
\text { (€000s) }\end{array}$} & \multicolumn{2}{|c|}{$\begin{array}{c}\text { Earning Assets } \\
\text { (€000s) }\end{array}$} & \multicolumn{2}{c|}{$\begin{array}{c}\text { Shares and Deposits } \\
\text { (€000s) }\end{array}$} & \multicolumn{2}{c|}{$\begin{array}{c}\text { Bad Debt Proxy } \\
\text { (€000s) }\end{array}$} \\
\hline Year & Average & $\begin{array}{c}\text { Standard } \\
\text { Deviation }\end{array}$ & Average & $\begin{array}{c}\text { Standard } \\
\text { Deviation }\end{array}$ & Average & $\begin{array}{l}\text { Standard } \\
\text { Deviation }\end{array}$ & Average & $\begin{array}{l}\text { Standard } \\
\text { Deviation }\end{array}$ \\
\hline $\mathbf{2 0 0 2}$ N=400 & 11,200 & 15,031 & 7,954 & 11,119 & 17,027 & 21,853 & 237 & 386 \\
\hline $\mathbf{2 0 0 5}$ N=400 & 14,558 & 19,672 & 15,288 & 22,157 & 26,710 & 35,637 & 417 & 643 \\
\hline $\mathbf{2 0 0 8}$ N=399 & 16,013 & 21,796 & 14,794 & 20,806 & 27,266 & 34,973 & 614 & 954 \\
\hline $\mathbf{2 0 1 1}$ N=381 & 13,902 & 18,851 & 20,906 & 27,002 & 30,285 & 37,450 & 259 & 463 \\
\hline $\mathbf{2 0 1 3}$ N=386 & 10,784 & 13,899 & 24,587 & 31,284 & 29,660 & 36,291 & 181 & 617 \\
\hline Total & 13,728 & 18,611 & 16,288 & 23,272 & 26,331 & 34,138 & 458 & 845 \\
\hline
\end{tabular}

\begin{tabular}{|c|c|c|c|c|c|c|}
\hline \multicolumn{7}{|c|}{ Panel B: Model Inputs } \\
\hline & \multicolumn{2}{|c|}{$\begin{array}{c}\text { Labour Expenditures } \\
\text { (€000s) }\end{array}$} & \multicolumn{2}{c|}{$\begin{array}{c}\text { Capital Expenditures } \\
\text { (€000s) }\end{array}$} & \multicolumn{2}{c|}{$\begin{array}{c}\text { Interest Expenditures } \\
\text { (€000s) }\end{array}$} \\
\hline & Average & $\begin{array}{l}\text { Standard } \\
\text { Deviation }\end{array}$ & Average & $\begin{array}{l}\text { Standard } \\
\text { Deviation }\end{array}$ & Average & $\begin{array}{l}\text { Standard } \\
\text { Deviation }\end{array}$ \\
\hline 2002 & 158 & 178 & 292 & 311 & 380 & 657 \\
\hline 2005 & 229 & 261 & 424 & 466 & 426 & 690 \\
\hline 2008 & 288 & 330 & 534 & 610 & 566 & 1,013 \\
\hline 2011 & 333 & 389 & 345 & 405 & 471 & 951 \\
\hline 2013 & 333 & 382 & 376 & 427 & 469 & 623 \\
\hline Total & 264 & 313 & 433 & 541 & 485 & 803 \\
\hline
\end{tabular}




\begin{tabular}{|c|c|c|c|c|c|c|c|c|}
\hline \multicolumn{7}{|c|}{ Panel C: Financial Viability Characteristics } \\
\hline & \multicolumn{2}{|c|}{ Total Assets(€000s) } & \multicolumn{2}{|c|}{$\begin{array}{r}\text { Loan book/total assets } \\
(\%)\end{array}$} & \multicolumn{2}{c|}{$\begin{array}{c}\text { Return on Assets } \\
(\%)\end{array}$} & \multicolumn{2}{c|}{$\begin{array}{c}\text { Capital Adequacy } \\
(\%)\end{array}$} \\
\hline & Mean & Std. Dev. & Mean & Std. Dev. & Mean & Std. Dev. & Mean & Std. Dev. \\
\hline 2002 & 19,698 & 25,525 & $56.95 \%$ & $13.61 \%$ & $0.82 \%$ & $1.50 \%$ & $10.08 \%$ & $2.96 \%$ \\
\hline 2005 & 30,747 & 41,076 & $49.36 \%$ & $12.78 \%$ & $0.74 \%$ & $1.55 \%$ & $10.45 \%$ & $3.13 \%$ \\
\hline 2011 & 31,819 & 40,689 & $51.66 \%$ & $14.06 \%$ & $2.78 \%$ & $2.35 \%$ & $13.75 \%$ & $3.19 \%$ \\
\hline Total & 30,659 & 39,826 & $47.23 \%$ & $14.78 \%$ & $1.61 \%$ & $1.95 \%$ & $12.58 \%$ & $3.79 \%$ \\
\hline
\end{tabular}

Table 3: Preliminary model specification tests

\begin{tabular}{|l|l|l|l|l|l|}
\hline Test Question & Model & Test type & $\begin{array}{l}\text { Degrees of } \\
\text { freedom }\end{array}$ & $\chi^{2}$ Statistics & Result \\
\hline $\begin{array}{l}\text { Non-frontier versus } \\
\text { Frontier }\end{array}$ & $\begin{array}{l}\text { Translog with } \\
\text { time trend }\end{array}$ & $\begin{array}{l}\text { Likelihood ratio } \\
\text { test }\end{array}$ & 2 & 604.90 & $\begin{array}{l}\text { Non-frontier } \\
\text { model rejected }\end{array}$ \\
\hline $\begin{array}{l}\text { Common frontier } \\
\text { versus latent class } \\
\text { frontier }\end{array}$ & $\begin{array}{l}\text { Translog with } \\
\text { time trend }\end{array}$ & $\begin{array}{l}\text { Likelihood ratio } \\
\text { test }\end{array}$ & 30 & 524.43 & $\begin{array}{l}\text { Common frontier } \\
\text { model rejected }\end{array}$ \\
\hline
\end{tabular}

Table 4: Optimal class identification tests

\begin{tabular}{|c|c|c|c|c|}
\hline Classes & Conditional & Log-Likelihood & Akaike (AIC) & Schwarz Bayesian (SBIC) \\
\hline 1 & No & 3173.96 & -1.334 & -1.206 \\
\hline 2 & Yes & 3037.08 & -1.287 & -1.198 \\
\hline 3 & Yes & 3290.81 & -1.438 & -1.391 \\
\hline 4 & Yes & 3055.11 & -1.301 & -1.212 \\
\hline
\end{tabular}

The optimal model will have the larger log likelihood and the lower (most negative) information criteria (AIC and SBIC). 
Table 5: Frontier estimation results for common and optimal latent class frontiers.

\begin{tabular}{|c|c|c|c|c|c|c|c|c|}
\hline \multicolumn{9}{|c|}{ Panel A: Distance Function Parameter Estimates } \\
\hline \multirow{3}{*}{ Class } & \multicolumn{2}{|c|}{ Common frontier } & \multicolumn{6}{|c|}{ Latent class frontier } \\
\hline & \multirow[b]{2}{*}{ Coefficients } & \multirow[b]{2}{*}{$\begin{array}{l}\text { Standard } \\
\text { Errors }\end{array}$} & \multicolumn{2}{|l|}{1} & \multicolumn{2}{|c|}{2} & \multicolumn{2}{|l|}{3} \\
\hline & & & Coefficients & $\begin{array}{c}\text { Standard } \\
\text { Errors }\end{array}$ & Coefficients & $\begin{array}{c}\text { Standard } \\
\text { Errors }\end{array}$ & Coefficients & $\begin{array}{c}\text { Standard } \\
\text { Errors }\end{array}$ \\
\hline Constant & $-0.267 * * *$ & 0.006 & $-0.356 * *$ & 0.160 & $-0.259 * * *$ & 0.011 & $-0.363 * * *$ & 0.045 \\
\hline$\beta_{1}$ & $0.133^{* * *}$ & 0.024 & $0.315^{* * *}$ & 0.033 & $0.182^{* * *}$ & 0.045 & $0.082^{* *}$ & 0.008 \\
\hline$\beta_{3}$ & $0.471 * * *$ & 0.043 & 0.08 & 0.057 & $0.36 * * *$ & 0.084 & $0.882 * * *$ & 0.101 \\
\hline$\alpha_{1}$ & $-0.229 * * *$ & 0.007 & $-0.106 * * *$ & 0.009 & $-0.228 * * *$ & 0.012 & $-0.364 * * *$ & 0.018 \\
\hline$\alpha_{2}$ & $-0.116^{* * *}$ & 0.008 & $-0.071 * * *$ & 0.013 & $-0.12 * * *$ & 0.012 & $-0.043 * *$ & 0.020 \\
\hline$\alpha_{3}$ & $-0.135 * * *$ & 0.004 & $-0.292 * * *$ & 0.008 & $-0.149 * * *$ & 0.009 & $-0.018 * * *$ & 0.007 \\
\hline$\gamma_{1}$ & $-0.025 * * *$ & 0.003 & $-0.033 * * *$ & 0.005 & $-0.001 * *$ & 0.001 & $-0.078 * * *$ & 0.011 \\
\hline$\beta_{11}$ & -0.017 & 0.017 & $0.126 * * *$ & 0.025 & $-0.064 * *$ & 0.028 & -0.029 & 0.046 \\
\hline$\beta_{33}$ & $-0.107^{* *}$ & 0.044 & -0.074 & 0.054 & -0.032 & 0.082 & $-0.382 * * *$ & 0.112 \\
\hline$\alpha_{11}$ & $-0.041 * * *$ & 0.002 & $-0.009 * * *$ & 0.002 & $-0.051^{* * *}$ & 0.003 & $-0.026 * * *$ & 0.007 \\
\hline$\alpha_{12}$ & $0.022^{* * *}$ & 0.003 & $-0.03 * * *$ & 0.004 & $0.053 * * *$ & 0.004 & -0.006 & 0.012 \\
\hline$\alpha_{22}$ & $-0.014 * * *$ & 0.005 & $0.038^{* * *}$ & 0.007 & $-0.085^{* * *}$ & 0.006 & $0.039 * *$ & 0.019 \\
\hline$\alpha_{13}$ & $0.004 * * *$ & 0.001 & $0.018^{* * *}$ & 0.001 & -0.001 & 0.001 & -0.001 & 0.002 \\
\hline$\alpha_{33}$ & $-0.023 * * *$ & 0.001 & $-0.048 * * *$ & 0.001 & $-0.027 * * *$ & 0.002 & $-0.003 * * *$ & 0.001 \\
\hline$\alpha_{23}$ & $0.015^{* * *}$ & 0.001 & $0.026 * * *$ & 0.002 & $0.027^{* * *}$ & 0.002 & 0.002 & 0.002 \\
\hline$\rho_{11}$ & $-0.023 * *$ & 0.011 & -0.006 & 0.014 & $-0.089 * * *$ & 0.015 & 0.017 & 0.029 \\
\hline$\rho_{21}$ & 0.006 & 0.015 & -0.024 & 0.021 & $0.103 * * *$ & 0.020 & -0.054 & 0.049 \\
\hline$\rho_{31}$ & 0.001 & 0.004 & $0.02 * * *$ & 0.007 & 0.008 & 0.006 & -0.014 & 0.010 \\
\hline$\rho_{13}$ & $0.046^{* *}$ & 0.020 & 0.022 & 0.024 & $0.151^{* * *}$ & 0.031 & -0.076 & 0.049 \\
\hline$\rho_{23}$ & -0.022 & 0.029 & 0.05 & 0.037 & $-0.208 * * *$ & 0.042 & 0.109 & 0.088 \\
\hline$\rho_{33}$ & -0.004 & 0.008 & $-0.029 * *$ & 0.012 & 0.001 & 0.012 & 0.013 & 0.019 \\
\hline$\phi_{11}$ & $0.009 * * *$ & 0.003 & -0.001 & 0.005 & $0.011^{* * *}$ & 0.004 & $0.046 * * *$ & 0.010 \\
\hline$\phi_{31}$ & $-0.024 * * *$ & 0.006 & $-0.018^{*}$ & 0.009 & $-0.021 * *$ & 0.009 & $-0.067 * * *$ & 0.022 \\
\hline$\eta_{11}$ & 0.001 & 0.001 & $0.007 * * *$ & 0.002 & $-0.004 * * *$ & 0.001 & -0.004 & 0.003 \\
\hline$\eta_{21}$ & 0.001 & 0.001 & 0.001 & 0.002 & $0.01 * * *$ & 0.001 & 0.006 & 0.004 \\
\hline$\eta_{31}$ & -0.001 & 0.001 & $-0.006 * * *$ & 0.001 & $-0.004 * * *$ & 0.001 & $0.002^{*}$ & 0.001 \\
\hline$\gamma_{11}$ & $-0.004 * * *$ & 0.000 & $-0.003^{* * *}$ & 0.001 & $-0.002 * *$ & 0.001 & $-0.013 * * *$ & 0.002 \\
\hline$\theta$ & $0.014 * * *$ & 0.001 & $0.005^{* * *}$ & 0.001 & $0.014^{* * *}$ & 0.001 & $0.022 * * *$ & 0.002 \\
\hline \multicolumn{9}{|c|}{ Panel B: Efficiency Parameters } \\
\hline Sigma & $0.194 * * *$ & 0.0004 & $0.082 * * *$ & 0.002 & $0.185^{* * *}$ & 0.005 & $0.092 * * *$ & 0.008 \\
\hline Lambda & $1.655^{* * *}$ & 0.053 & 0.002 & 0.04 & $4.322 * * *$ & 0.617 & 0.212 & 0.623 \\
\hline \multicolumn{9}{|c|}{ Panel C: Class Membership Probability Parameters } \\
\hline Constant & & & $-2.791 * * *$ & 0.472 & -0.437 & 0.550 & \multicolumn{2}{|c|}{ Reference Group } \\
\hline $\begin{array}{l}\text { Loan book/ } \\
\text { total assets }\end{array}$ & 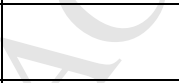 & & $0.024 * * *$ & 0.006 & $-0.033 * * *$ & 0.007 & \multicolumn{2}{|c|}{ Reference Group } \\
\hline $\begin{array}{c}\text { Return on } \\
\text { Assets }\end{array}$ & & & $0.132 * *$ & 0.056 & $0.18^{* * *}$ & 0.062 & \multicolumn{2}{|c|}{ Reference Group } \\
\hline $\begin{array}{c}\text { Capital } \\
\text { Adequacy }\end{array}$ & & & $0.169 * * *$ & 0.030 & $0.193 * * *$ & 0.033 & \multicolumn{2}{|c|}{ Reference Group } \\
\hline Observations & \multicolumn{2}{|c|}{4618} & \multicolumn{2}{|c|}{$1874(41 \%)$} & \multicolumn{2}{|c|}{$2008(43 \%)$} & \multicolumn{2}{|c|}{$736(16 \%)$} \\
\hline \multicolumn{3}{|c|}{ Prior membership probabilities } & \multicolumn{2}{|c|}{0.384} & \multicolumn{2}{|c|}{0.416} & \multicolumn{2}{|c|}{0.2} \\
\hline
\end{tabular}


Table 6: Mean efficiency and financial ratio analysis by latent class

\begin{tabular}{|c|c|c|c|c|}
\hline Model Type & Efficiency & $\begin{array}{c}\text { Return on } \\
\text { Assets (\%) }\end{array}$ & $\begin{array}{c}\text { Capital } \\
\text { Adequacy (\%) }\end{array}$ & $\begin{array}{c}\text { Loan book/ } \\
\text { total assets (\%) }\end{array}$ \\
\hline Latent Class Frontier Model & & & & \\
\hline $1(41 \%)$ & 0.961 & 1.66 & 12.39 & 56.24 \\
\hline $2(43 \%)$ & 0.868 & 1.95 & 13.94 & 38.19 \\
\hline $3(16 \%)$ & 0.951 & 0.56 & 9.36 & 48.94 \\
\hline Overall average & 0.919 & 1.61 & 12.58 & 47.23 \\
\hline Common Frontier Model & 0.964 & & & \\
\hline
\end{tabular}

Table 7: A profile of credit union characteristics by latent class

\begin{tabular}{|c|c|c|c|c|c|c|c|}
\hline & \multicolumn{2}{|c|}{ Location } & \multicolumn{2}{c|}{ Common Bond } & \multicolumn{2}{c|}{ Trade Association } & \\
\hline Class & Urban & Rural & Occupational & Geographical & CUDA* & ILCU* & Mean Total Assets (€) \\
\hline 1 & $57.9 \%$ & $39.6 \%$ & $58.7 \%$ & $47.5 \%$ & $38.8 \%$ & $40.7 \%$ & $27,013,423$ \\
\hline 2 & $27.3 \%$ & $40.2 \%$ & $29.5 \%$ & $34.3 \%$ & $49.5 \%$ & $43.3 \%$ & $36,127,283$ \\
\hline 3 & $14.8 \%$ & $20.2 \%$ & $11.7 \%$ & $18.2 \%$ & $11.7 \%$ & $16.0 \%$ & $24,532,007$ \\
\hline
\end{tabular}

*Irish League of credit Unions (ILCU); Credit Unions Development Association (CUDA)

Table 8: Returns to scale analysis

\begin{tabular}{|c|c|c|c|}
\hline Model Type & Returns to Scale & $95 \%$ lower limit & 95\% Upper Limit \\
\hline Class 1 & 0.9705 & 0.9703 & 0.9708 \\
\hline Class 2 & 0.9962 & 0.9751 & 1.0180 \\
\hline Class 3 & 0.9283 & 0.9278 & 0.9287 \\
\hline Global returns to scale & 0.9727 & 0.9531 & 0.9921 \\
\hline Common Frontier Model & 1.0160 & 0.9858 & 1.0361 \\
\hline
\end{tabular}

Table 9: Returns to scale analysis using a extended sample period approach

\begin{tabular}{|l|l|l|l|}
\hline Sample Period & Global Returns to Scale (GRTS) & $95 \%$ lower limit & $95 \%$ Upper Limit \\
\hline $2002-2008$ & 1.080 & 1.056 & 1.104 \\
\hline $2002-2009$ & 1.061 & 0.882 & 1.239 \\
\hline $2002-2010$ & 1.022 & 0.971 & 1.073 \\
\hline $2002-2011$ & 1.018 & 0.994 & 1.042 \\
\hline $2002-2012$ & 0.981 & 0.961 & 1.001 \\
\hline $2002-2013$ & 0.973 & 0.953 & 0.992 \\
\hline
\end{tabular}

